\title{
DIREITO AMBIENTAL NO CONTEXTO DA SOCIEDADE DE RISCO: UMA ANÁLISE SOBRE AS ÁREAS CONTAMINADAS
}

José Fernando Vidal de Souza

\begin{abstract}
Pós-doutor pelo Centro de Estudos Sociais (CES) da Faculdade de Economia da Universidade de Coimbra (2007). Pós-doutor pela Universidade Federal de Santa Catarina (2013) Doutor (2003) e Mestre (1997), em Direito pela Pontifícia Universidade Católica de São Paulo, Especialista em Ciências Ambientais pela Universidade São Francisco (2000). Bacharel em Direito pela Pontifícia Universidade Católica de Campinas (1986). Bacharel em Filosofia pela Pontifícia Universidade Católica de Campinas (2011). Atualmente é professor da Universidade Nove de Julho (UNINOVE) e da Universidade Paulista (UNIP). Promotor de Justiça do Ministério Público do Estado de São Paulo.
\end{abstract}

\section{Resumo}

O artigo se propóe a examinar a proteçáo da qualidade do solo, as medidas contra as alteraçóes nocivas por contaminação e o gerenciamento de áreas contaminadas, diante da realidade brasileira em um contexto de sociedade de risco. Para tanto, parte-se da explicação do direito ao meio ambiente ecologicamente equilibrado no âmbito do direito brasileiro e da ética ambiental. Em seguida, examina-se o conceito de sociedade de risco. Depois, a problemática dos solos contaminados no Brasil e, ao final, apresentam-se as técnicas para recuperação dos solos contaminados. Desta maneira, são analisados, também, os processos que geraram o passivo ambiental, as iniciativas para minimizar os riscos desses impactos e os instrumentos hoje disponíveis para seu enfrentamento: considerados como elementos imprescindíveis para subsídio às políticas voltadas à requalificação urbana de áreas contaminadas.

\section{Palavras-chave}

Áreas contaminadas; Sociedade de risco; Passivo ambiental; Qualidade do solo; Ética ambiental.

\section{Abstract}

The article aims to analyze the protection of soil quality, measures against harmful contamination of change and the management of contaminated areas, before the Brazilian reality in a risk society context. Therefore, examines the right to an ecologically balanced environment under Brazilian law and environmental ethics. Then the concept of risk 
society. After the contaminated soil problems in Brazil and in the end present techniques for remediation of contaminated soils. In this way, are analyzed also the processes that generated the environmental liability, initiatives to minimize the risks of these impacts and the tools available today for its confrontation: considered as essential elements for subsidizing policies aimed at urban regeneration of contaminated areas.

\section{Key words}

Contaminated areas; Risk society; Soil quality; Environmental liability; Environmental ethics.

\section{Introdução}

O presente artigo se propóe a examinar a proteçáo da qualidade do solo, as medidas contra as alteraçóes nocivas por contaminação e o gerenciamento de áreas contaminadas, diante da realidade brasileira.

Como se sabe a Revolução Industrial altera significativamente os hábitos e os costumes da humanidade, gerando diversas transformaçôes sociais, políticas e econômicas.

$\mathrm{O}$ crescimento desenfreado de máquinas, indústrias, obras e instalaçóes acabaram por gerar um acúmulo de danos ambientais que devem ser reparados para garantir a qualidade de vida das geraçóes presentes e futuras.

Ao longo desse período o mundo passou a conviver com um crescente passivo ambiental decorrente da dinâmica da vida moderna nas cidades e no campo, tais como depósitos de resíduos, uso de agrotóxicos, vazamentos de tubulação e tanques enterrados, vazamentos de combustíveis, etc, sendo que durante muito tempo inexistiu qualquer discussão sobre recuperação de áreas contaminadas, gerenciamento de resíduos e gestão de recursos hídricos.

Com isso tem-se que a Revoluçáo Industrial de um lado possibilita o avanço tecnológico e cientifico, mas de outro enseja que o planeta seja explorado de maneira intensa e predatória, na tentativa de extrair recursos naturais que, em tese, deveriam propiciar maiores benefícios para a humanidade.

O resultado dessa busca incessante por matéria-prima e produção de bens e produtos, em épocas de ausência de regras de proteção e gestão ambiental, redundou no surgimento de várias modalidades de poluiçãao, dentre elas a poluição do solo e das águas superficiais e subterrâneas e, consequentemente, um risco para a saúde humana.

Com efeito, é certo que na Inglaterra, no início do século XIX, já se registravam problemas de poluição do solo e dos rios pela intensa descarga de dejetos, inclusive industriais, que causaram epidemias de cólera e febre tifoide. 
No Brasil, em razão de um modelo desenvolvimentista mais atrasado, os problemas ambientais referentes à poluição do solo começam a surgir de forma mais intensa nas décadas de 1930 a 1950, quando há uma expansão industrial no país.

Porém, em termos mundiais somente a partir final da década de 1960 é que surge uma preocupação com a poluição dos solos.

De fato, começam a surgir, em escala mundial uma série de problemas oriundos da intensa atividade industrial e agrícola que levam os países a discutirem mecanismos para recuperação de áreas degradadas e contaminadas, resíduos e gestão de recursos hídricos.

É a percepção social global que impulsiona a humanidade a rever o modelo da sociedade de consumo surgido a partir da Revolução Industrial, exigindo um intenso debate sobre o destino ambiental planetário, mostrando a necessidade de modificaçáo dos modelos sistemáticos de produção e gestão ambiental, face os perigos e as incertezas do futuro do homem.

Assim, o presente artigo tem seu início com uma explicação do direito ao meio ambiente ecologicamente equilibrado no âmbito do direito brasileiro. Em seguida, debruçase sobre o conceito de sociedade de risco. Depois, parte-se para análise da problemática dos solos contaminados no Brasil. Ao final pretende-se mostrar o atual estado da arte e as técnicas para recuperação dos solos contaminados.

Desta forma, propóe-se a análise da temática cuja importância se revela inequívoca na medida em que sua existência constitui fato sobre o qual se deparam os operadores do Direito com não rara frequência, merecendo, portanto, a tecer algumas consideraçóes acerca das características e natureza principiológica decorrentes da ideia de prevenção e reparação.

É nesse contexto que se encontra inserido o objeto central do presente estudo, qual seja avaliar a existência de áreas contaminadas ou ainda suspeitas de contaminação e dos instrumentos legais de gerenciamento existentes que não funcionam para esta sociedade, numa releitura de antigos direitos em face da construção de uma nova e necessária realidade. (sociedade de risco).

Por fim, serão analisados os processos que geraram o passivo ambiental, as iniciativas para minimizar os riscos desses impactos e os instrumentos hoje disponíveis para seu enfrentamento: considerados como elementos imprescindíveis para subsídio às políticas voltadas à requalificação urbana de áreas contaminadas.

\section{Direito ao Meio Ambiente Ecologicamente Equilibrado no Âmbito do Direi- to Brasileiro}

O aumento do consumo, o pensamento linear e determinista de utilização da natureza para suprir e servir o homem e a globalização do consumo acentuaram o estado de degradaçáo ambiental que vemos na atualidade. 
Neste particular Ulrich Beck (2011, p.23) enfatiza que:

$\mathrm{Na}$ modernidade tardia, a produção social de riqueza é acompanhada sistematicamente pela produçấo social de riscos. Consequentemente, aos problemas e conflitos distributivos da sociedade da escassez sobrepóemse os problemas e conflitos sugeridos a partir da produçáo, definiçáo e distribuição de riscos cientifico-tecnologicamente produzidos.

Tudo isso vem obrigando os países a buscar a conservaçáo ambiental e o aproveitamento dos recursos naturais de forma integrada, de tal forma que os problemas ambientais atuais devem ser enfrentados com um modelo legislativo robusto capaz de diminuir os danos infligidos, por décadas, ao meio ambiente.

Neste sentido, a Constituição República Federativa do Brasil de 1988 traz, pela primeira vez, a proteção ao meio ambiente como matéria constitucional, tornando-o um bem jurídico, no qual todo indivíduo tem o direito fundamental de desfrutar de um meio ambiente sadio.

Além disso, é dever do Poder Público e de toda a coletividade defender o meio ambiente ecologicamente equilibrado, para preservá-lo para as presentes e futuras geraçóes, justificando-se a intervenção do Estado para controlar as atividades econômicas e o emprego de técnicas, métodos e substâncias que coloquem em risco a vida, a qualidade de vida e o meio ambiente $\left(\mathrm{CF} / 88\right.$, artigo $\left.225, \$ 1^{\circ}, \mathrm{V}\right)$.

Tem-se com isso que a sadia qualidade de vida pressupóe o respeito ao direito ao meio ambiente ecologicamente equilibrado, que integra a dignidade da existência — objetivo da ordem econômica (CF/88, art. 170) — e o bem-estar de todos — objetivo da ordem social (CF/88, art. 193). Portanto, o direito fundamental ao meio ambiente ecologicamente equilibrado é bem de uso comum do povo, o que indica a sua natureza jurídica de bem difuso.

A leitura dos dispositivos afasta a possibilidade de adoção de um modelo técnicocientífico de domínio da natureza ou da visão de que esta seja um mero reservatório de matéria-prima para favorecimento do homem.

No contexto atual, como revela Ulrich Beck (2011, p.24):

Não se trata mais, portanto, ou não se trata mais exclusivamente de uma utilização econômica da natureza para libertar as pessoas de sujeiçóes tradicionais, mas também e sobretudo de problemas decorrentes do próprio desenvolvimento técnico-econômico. $\mathrm{O}$ processo de modernização torna-se "reflexivo", convertendo-se a si mesmo em tema e problema. Às questóes do desenvolvimento e do emprego de tecnologias (no âmbito da natureza, da sociedade e da personalidade) sobrepóem-se questôes do "manejo" político e científico - administração, descoberta, integração, 
prevenção, acobertamento - dos riscos de tecnologias efetiva ou potencialmente empregáveis, tendo em vista horizontes de relevância a serem especificamente definidos.

À vista disso, para se assegurar uma vida saudável é necessário se satisfazer os critérios de uma existência humana digna, na qual o homem não pode viver dissociado da natureza. Por isso, o art. 225 da CF/88 deve ser lido em consonância com os seguintes artigos do Texto Maior: a) art. $1^{\circ}$, III, que prevê da proteção à dignidade; b) art. $3^{\circ}$, I, que prevê a solidariedade social; c) art. $3^{\circ}$, III, que estabelece como objetivos do Estado brasileiro a erradicação da pobreza, da marginalização e da redução das desigualdades sociais e regionais; d) art. 7º, IV, que estabelece o salário mínimo familiar.

Com efeito, a fundamentação do acórdão (ADI 3.540-MC/DF pelo Supremo Tribunal Federal - STF), no voto do Ministro relator Celso de Mello, deixa claro o sentido de preservação da integridade do meio ambiente como expressão constitucional de um direito fundamental que assiste à generalidade das pessoas, nos moldes do artigo 225, caput, da CF/88 e traduz uma das mais expressivas prerrogativas asseguradas às formaçóes sociais contemporâneas:

Trata-se, consoante já o proclamou o Supremo Tribunal Federal, de um típico direito de terceira geração (ou de novíssima dimensão), que assiste, de modo subjetivamente indeterminado, a todo o gênero humano, circunstância essa que justifica a especial obrigação - que incumbe ao Estado e à própria coletividade - de defendê-lo e de preservá-lo em benefício das presentes e futuras geraçóes, evitando-se, desse modo, que irrompam, no seio da comunhão social, os graves conflitos intergeneracionais marcados pelo desrespeito ao dever de solidariedade na proteçâo da integridade desse bem essencial de uso comum de todos quantos compóem o grupo social." E consta o seguinte na ementa desse aresto: "A preservaçáo da integridade do meio ambiente: expressão constitucional de um direito fundamental que assiste à generalidade das pessoas.”

Assim, lê-se no RE 134.297-8/SP (DJ 22.09.95), o rel. Min. Celso de Mello: "Direito ao meio ambiente ecologicamente equilibrado: a consagração constitucional de um típico direito de terceira geração $(\mathrm{CF}$, art. 225, caput)". Da mesma forma, no MS 22.164-0/SP, rel. o Min. Celso de Mello, (DJ 17/11/95, 39206): "A questão do direito ao meio ambiente ecologicamente equilibrado. Direito de terceira geração. Princípio da solidariedade. [...] os direitos de terceira geração, que materializam poderes de titularidade coletiva atribuídos genericamente a todas as formações sociais, consagram o princípio da solidariedade e constituem um momento importante no processo de desenvolvimento, expansão e reconhecimento de direitos humanos, caracterizados, enquanto valores fundamentais indisponíveis, pela nota de uma essencial inexauribilidade”. 
À vista de tais consideraçóes e para atender aos objetivos exigidos pelo art. $225 \mathrm{da}$ $\mathrm{CF} / 88$, especialmente no que se refere à proteção do meio ambiente em face das atividades potencialmente poluidora é que se se propóe o princípio da prevenção a ser aplicado sempre que houver uma atividade sabida e comprovadamente causadoras de dano ambiental.

Para que seja possível uma conceituação mais precisa do princípio da prevenção fazse necessário estabelecer uma relação entre ele e o princípio da precaução, delimitando as principais características de ambos.

Parte da doutrina entende que a distinção entre precaução e prevenção se dá pela distinção entre risco (que corresponde à precaução) e perigo (que corresponde à prevenção).

O risco pode ser definido como a possibilidade de ocorrência de uma situação de perigo. Este, por sua vez, consiste na possibilidade da ocorrência de um dano. Ou seja, o princípio da prevenção se dá em relação ao perigo concreto, enquanto que, em se tratando do princípio da precaução, a prevenção é dirigida à possibilidade do perigo abstrato.

O princípio da precaução não funciona em detrimento da ciência, pelo contrário, conduz à obrigação juridicamente sancionada de adquirir o conhecimento sobre o risco.

Constata-se, pois, que a prevenção dos danos ambientais deve ser a primeira prioridade, dado que nada é mais rentável e nada protege mais os ecossistemas e a saúde dos seres vivos.

Desta maneira, o princípio da prevenção é invocado para proibir uma atividade comprovadamente perigosa, uma vez que há informaçóes certas e precisas sobre sua periculosidade e o perigo fornecido, que, revela situação de maior verossimilhança do potencial lesivo que aquela controlada pelo princípio da precaução. Este, por sua vez, aplica-se nas situaçóes onde haja risco de perigo potencial, isto é, há evidências verossímeis que levam a considerar que determinada atividade seja perigosa, não sendo possível qualificar o risco nem quantificar seus efeitos devido à insuficiência ou caráter inconclusivo dos dados científicos disponíveis. (LEITE e AYALA, 2002 p 57).

Então, de um lado, conhecendo-se os riscos que certa atividade gera para o meio ambiente há a possibilidade de invocar-se o princípio da prevenção para adoção de medidas preventivas ou para sua não efetivação.

Do outro lado, não havendo certeza sobre os riscos, devem ser realizados estudos para tentar dimensioná-los, podendo ser inviabilizada a atividade nos casos de estudos inconclusivos invocando-se o princípio da precaução.

Enfim, aplica-se à espécie o principio da prevenção segundo o qual se deve impedir a ocorrência de danos ao meio ambiente, pela adoção de cautelas, antes da efetiva execução de atividades potencialmente poluidoras e/ou utilizadoras de recursos naturais. O referido princípio é aplicável nas hipóteses em que os riscos são conhecidos e previsíveis. 
Como enfatiza José Fernando Vidal de Souza (2011, p. 395):

O princípio da prevenção, ao contrário do princípio da precaução, foi idealizado para identificar as consequências prejudiciais de certas atividades particulares. Seu objetivo não é outro senão representar uma advertência ou reprimenda para evitar que se produzam danos ambientais. Pela prevenção é possível examinar a viabilidade do empreendimento, que, por meio do conhecimento científico, poderá ser admitido mediante a correção dos riscos apontados no estudo de impacto ambiental.

Contudo, o risco ambiental é intrínseco às atividades industriais em razão da natureza do processo produtivo, das matérias primas e insumos utilizados e dos tipos de resíduos gerados, ou seja, o risco não é invenção da modernidade.

Contudo, como ressalta Ulrich Beck (2011, p. 73):

A produção de riscos e sua interpretação equivocada têm, portanto, seu primeiro fundamento numa "miopia econômica" da racionalidade técnica das ciências naturais. Seu olhar está dirigido às vantagens produtivas. Ele incide assim juntamente com uma cegueira em relação aos riscos que é sistematicamente provocada. Enquanto as possibilidades de aplicabilidade econômica são claramente previstas, desenvolvidas, testadas, e, de acordo com todas as regras da arte, esclarecidas, no caso dos riscos é sempre necessário tatear no escuro e então deixar-se surpreender e consternar profundamente com seu aparecimento "imprevisto" ou mesmo "imprevisível”.

Ademais, em geral os problemas ambientais transcendem as fronteiras, por isso, há uma democratização dos riscos, já que os problemas ambientais causados pela contaminação não ficam restritos apenas à área onde a contaminação foi gerada, há uma globalização dos riscos que não mais se restringem a fronteiras geográficas e classes sociais, podendo os danos se estender por diversas geraçóes.

De fato, como enfatizam Vidal de Souza e Horbatiuk Dutra (2011, p. 9), "a sociedade de risco estabelece uma imbricada e complexa relação do pensamento científico, da economia e da política com o ecossistema e as comunidades humanas". Desta maneira, arrematam os autores, "o que afeta o meio ambiente não se limita a causar prejuízos ao sistema ecológico como um todo; repercute direta ou indiretamente na qualidade de vida humana, interferindo na saúde e segurança, influindo em suas práticas cotidianas, atingindo aspectos essenciais à sua dignidade".

Por isso, diante da gravidade do quadro da sociedade de risco e dos danos ambientais por ela gerados, identificar as possíveis causas do risco é o ponto de partida para a construção de alternativas que coadunem o equilíbrio ecossistêmico e o processo humano civilizatório. 
Além disso, como explica Paulo Affonso Leme Machado (2012, p. 98) ao citar Michael Prieur, "o princípio da precaução é, atualmente, uma referência indispensável em todas as abordagens relativas aos riscos".

Não obstante tais consideraçóes, devemos ter em conta que, o princípio da prevenção, a educação e a informação ambiental são requisitos essenciais para a tomada de consciência da coletividade sobre a questão ambiental, olhar sobre outro prisma a sociedade de consumo, o que corresponde a adotar uma postura ética frente ao meio ambiental.

Com uma preocupação voltada a esta ideia, fundada numa visão da ética ambiental, Leonardo Boff (2011, p. 20) nos diz:

Há um descuido e um descaso na salvaguarda de nossa casa comum, o planeta Terra. Solos são envenenados, áreas são contaminadas, aguas são poluídas, florestas são dizimadas, espécies de seres vivos são exterminadas, um manto de injustiça e de violência pesa sobre dois terços da humanidade. Um princípio de autodestruição está em ação, capaz de liquidar o sutil equilíbrio físico-químico e ecológico do planeta e devasta a biosfera, ponde assim em risco a continuidade do experimento da espécie homo sapiens e demens.

A questão do pensar ecológico, portanto, pressupóe a existência de uma visão criativa da ética ambiental que amplia o olhar e enfatiza com veemência que estamos diante de um direito que não pertence a uma única pessoa ou a um grupo de pessoas, mas é de todos e, portanto, transindividual.

Na mesma linha de pensamento, José Renato Nalini (2010, p. XXVI a XXVII) adverte:

A ameaça ao ambiente é questão eminentemente ética. Depende de uma alteração de conduta. A antiga filosofia sustentava que a função do conhecimento era sustentar uma ética. (...) A proteção à natureza independe de educação, riqueza ou mesmo religião. Em todos os estamentos há infratores. A lei ambiental não tem sido freio suficiente. A proliferação normativa desativa a força intimidatória do ordenamento. Outras vezes, a sanção é irrisória e vale a penas suportá-la, pois a relação custo/benefício estimula a vulneração da norma. Apenas uma nova cultura ambiental poderá coibir a reiteração de práticas lesivas, hoje disseminadas e, pior ainda, toleradas. (...) A crise não é do ambiente. A crise é de valores. É uma crise ética.

Desta forma, frente à ineficiência da implementação das normas preventivas, a educação ambiental e a conscientização pública para a preservação do meio ambiente intensificam a meta de difusão da informação, conforme apresentado de forma cristalina no artigo 225, $\$ 1^{\circ}$, VI, da CF/88. 
De fato, a importância da participação da sociedade nas questóes ambientais foi prevista na Lei no 6.938/81, que estabeleceu a Política Nacional do Meio Ambiente no Brasil e elencou dentre os seus objetivos "a divulgação de dados e informaçóes ambientais e a formação de uma consciência pública sobre a necessidade de preservação da qualidade ambiental e do equilíbrio ecológico" (art. 4º, V).

A mesma trajetória seguiu a Resolução CONAMA 237/97 que previu em seu art. $3^{\circ}$ que ao EIA/RIMA (Estudo de Impacto Ambiental e Relatório de Impacto Ambiental) dar-se-á publicidade, garantida a realização de audiências públicas ...”.

Com isso, paulatinamente, o Princípio da Informação foi recebendo no Direito Ambiental uma densidade que não lhe era conferida antes.

Assim é que o art. $5^{\circ}$ da Lei $12.527 / 11$ passou a determinar que do Princípio da Informação decorre do dever de gerar e prestar a informação, competindo ao Estado o dever de garantir o direito de acesso à informaçáo, que deve ser franqueada, mediante procedimentos objetivos e ágeis, de forma transparente, clara e em linguagem de fácil compreensão.

Neste sentido, por exemplo, a existência de um sistema de informaçóes sobre as áreas contaminadas possibilita a gestão compartilhada, envolvendo os diferentes órgãos públicos, tanto da União como dos Estados e municípios. Parte-se da premissa de que qualquer atividade que atente conta o meio ambiente implica, por via oblíqua, numa agressão à própria sociedade, ainda que esta não venha a ser atingida imediatamente, mas possa implicar num risco para a saúde pública. (SOUZA, 2011, p. 388)

Portanto, o direito da informação, segundo os ensinamentos de Paulo Affonso Leme Machado são plenamente aplicáveis aos casos de áreas contaminadas.

No seu dizer, a informação ambiental "deve ser veraz, contínua, tempestiva e completa" (LEME MACHADO, 2006, p. 91), destacando ou identificando as características da tecnicidade, compreensibilidade e rapidez. Sobre a tecnicidade, leciona que a informação ambiental deve ser compreensível. "A informação necessita poder ser utilizada de imediato, sem que isso demande que os informados sejam altamente especializados no assunto”. (LEME MACHADO, 2006, p. 92.)

Para efeito da temática ora proposta é conveniente destacar que a Companhia Ambiental do Estado de São Paulo (CETESB) - agência do Governo do Estado de São Paulo, responsável pelo controle, fiscalização, monitoramento e licenciamento de atividades geradoras de poluição, com a preocupação fundamental de preservar e recuperar a qualidade das águas, do ar e do solo - foi o primeiro órgão de controle ambiental na América Latina a possuir um cadastro organizado de dados ambientais e disponibilizá-lo para consulta pública. Em maio de 2002 divulgou-se, pela primeira vez, o cadastro das áreas 
contaminadas no Estado de São Paulo. Na ocasião eram 255 e em sua última atualização, realizada em dezembro de 2013, esse número aumentou para 4.771.

Entretanto, esses números correspondem ainda a uma pequena parcela da realidade. Estima-se, com base no histórico da industrialização, que haja alguns milhares de áreas contaminadas no Estado de São Paulo, o mais industrializado da federação brasileira.

É certo que grande parte das áreas contaminadas advém de práticas e procedimentos com substâncias perigosas onde os cuidados com a proteção ao meio ambiente eram desconhecidas ou negligenciadas e à ocorrência de acidentes ou vazamentos durante o desenvolvimento dos processos produtivos, de transporte ou de armazenamento de matérias primas e produtos.

Neste contexto, a questão da contaminação do solo e das águas subterrâneas tem sido objeto de preocupação em países industrializados, e a Região Metropolitana de São Paulo ocupa maior evidência no Brasil.

Vale destacar ainda que no planejamento urbano, a contaminação por resíduos perigosos ou uso de substâncias químicas seja em áreas industriais desativadas antigas ou em operação, tem sido um problema muitas vezes não solucionado.

Neste particular é certo, por exemplo, que durante as últimas décadas do século XX a alternativa de utilização de água subterrânea tornou-se, regra geral, a solução mais barata aos problemas de abastecimento público, industrial e até irrigação.

Desta forma, a falta de um controle em prol do seu uso e proteção - Federal, Estadual ou Municipal torna-se cada vez mais preocupante. Em todas as áreas metropolitanas do Brasil vários milhares de poços privados e não controlados são utilizados para abastecimento de hotéis de luxo, hospitais, indústrias, condomínio, postos de serviço e clubes esportivos, sendo certo afirmar que há uma ligação direta entre a contaminação do solo e a poluição das águas subterrâneas.

Sabe-se, pois, que a água subterrânea contribui com mais de $95 \%$ para toda a água doce disponível no planeta.

No entanto, a confirmação da existência de alteração na qualidade do solo e/ou água subterrânea acima dos valores de referência vigentes, obriga o responsável pela área, que não necessariamente seja o responsável por causar o impacto ambiental ou dano, a recuperar a área, como preconiza o art. 20 da Lei 13.577/09 e o Manual de Gerenciamento de Áreas Contaminadas- CETESB de 2001, ao ditar que: "o processo de recuperação de áreas contaminadas tem como objetivo principal a adoção de medidas corretivas nessas áreas que possibilitem recuperá-las para um uso compatível com as metas estabelecidas a ser atingidas após a intervenção, adotando-se dessa forma o princípio da 'aptidão para o uso".

No âmbito brasileiro, a ideia da recuperação do dano, como primeira medida a ser tomada, está expressa no $\$ 2$ do art. 225 da CF/88, obrigando aquele que explorar atividades de mineração a recuperar o meio ambiente degradado. 
Ademais, o art 4º, VI da Lei 6.938/81 estabeleceu a "preservação e a restauração dos recursos ambientais com vistas à sua utilização racional e disponibilidade permanente, concorrendo para a manutenção do equilíbrio ecológico propício à vida”, o que implica ao poluidor, a obrigação de recuperar e/ou indenizar os danos causados, não estando estas hierarquicamente em pé de igualdade e independente de a primeira ser mais onerosa.

Como se constata, todo o arcabouço legislativo é voltado para a prevenção do dano e, se possível, para a sua reparação.

O referido princípio da prevenção é localizado, por exemplo, nos arts $4^{\circ}$, incisos III, IV e V e 10 da Lei no . 6938/81; no art. 225 caput e $\$ 1^{\circ}$, inciso IV da Constituição Federal e pelo princípio 17 da Declaração do Rio sobre o Meio Ambiente e Desenvolvimento e voltada para reparação, educação e repressão do dano ambiental.

É diante desse cenário que se pretende tecer algumas consideraçóes sobre as áreas contaminadas e a aplicação de alguns instrumentos do direito ambiental, levando-se em consideração o direito fundamental de desfrutar de um meio ambiente sadio, capaz de propiciar uma vida digna, tal qual prevê o direito fundamental assegurado pelo Texto maior em seu ar. $1^{\circ}$, inciso III.

Com tais consideraçóes é preciso ter claro que o objeto central do presente estudo, ou seja, uma análise das áreas contaminadas ou suspeitas de contaminação exige para sua correta compreensão uma explicação sobre conceitos da denominada sociedade de risco, como se verá a seguir.

\section{Contaminação do Solo e Sociedade de Risco}

A contaminação do solo e da água subterrânea decorrente das atividades industriais desenvolvidas, principalmente nas regióes economicamente mais ativas, só recentemente foi objeto de atenção por parte do poder público.

Cabe lembrar que os potenciais impactos decorrentes das atividades industriais não circunscrevem aos limites da propriedade.

Assim, falhas no processo produtivo, no gerenciamento dos resíduos ou no armazenamento de matérias-primas são as principais causas de contaminação, já que favorecem a percolação da contaminação, resultante de uma série de fatores, tais como a quantidade e as características físico-químicas das substâncias químicas envolvidas, a hidrogeologia, além do tempo de contato dos contaminantes com o meio.

Desta forma, as áreas contaminadas adquirem uma relevância maior quando possibilitam a exposição da população às substâncias, implicando, por consequência, a possíveis riscos à saúde humana. 
Ademais, o crescimento urbano desenfreado, aliado ao desenvolvimento econômico e à dinâmica da expansão imobiliária, tem permitido a ocupação desordenada para fins residenciais ou comerciais em áreas que no pretérito foram utilizadas para disposição de resíduos ou mesmo em áreas industriais desativadas.

Com isso, áreas centrais dos grandes centros urbanos, encontram-se contaminadas e/ ou abandonadas, e, muitas vezes, sua origem é desconhecida e remonta às épocas passadas, na qual os procedimentos não eram seguros para o manejo de substâncias perigosas e o desrespeito a esses procedimentos geravam a ocorrência de acidentes ou vazamentos durante o desenvolvimento dos processos produtivos, de transporte ou de armazenamento de matérias primas e produtos.

Diante de tais colocaçóes Anthony Giddens (1991, p. 18) resume a realidade atual ao destacar que "o mundo em que vivemos hoje é um mundo carregado e perigoso. Isto tem servido para fazer mais do simplesmente enfraquecer ou nos forçar a provar a suposição de que a emergência da modernidade levaria à formação de uma ordem social mais feliz e mais segura”.

A organização social atual exige uma preocupação com os conceitos de risco e perigo.

É na passagem da sociedade industrial para uma sociedade de risco que os riscos produzidos pela própria sociedade são distribuídos, ou seja, é no processo de globalização social e econômica que começa a ocorrer, também, o que ele denominou de globalização dos riscos.

Neste sentido, Ulrich Beck (1999) apresenta três cenários para a orientação política nesse contexto: o retorno à sociedade industrial, a democratização do desenvolvimento tecnológico e a emergência de políticas diferentes, o que requer novas instituiçóes políticas e novas deliberaçóes sobre o risco, com envolvimento das organizaçôes e da sociedade civil.

Como assevera o autor, a sociedade reflexiva do século XXI deve defrontar-se com o enfrentamento de cinco processos, que representam grandes desafios: globalização, individualização, desemprego e subemprego, a revolução dos gêneros e os riscos globais, resultantes tanto da crise ecológica como da turbulência dos mercados financeiros.

Por essa razão, Ulrich Beck (1999, p. 27-30) faz uma distinção entre globalismo, globalidade e globalização. Assim, no seu entender globalismo é "a concepção de que o mercado mundial bane ou substitui, ele mesmo, a ação política; trata-se, portanto, da ideologia do império do mercado mundial, da ideologia do neoliberalismo”. Globalidade é o fato de que "já vivemos, há tempos, em uma sociedade mundial; significa "o conjunto das relaçôes sociais, que não estão integradas à política do Estado nacional ou que não são determinadas (determináveis) por ela". Por fim, globalização significa "os processos, em cujo andamento os Estados nacionais veem a sua soberania, sua identidade, suas redes de 
comunicação, suas chances de poder e suas orientaçóes sofrerem interferência cruzada de atores transnacionais".

Os conceitos apontados são importantes para a compreensão de suas ideias, eis que no seu entender:

O reverso da natureza é a socialização dos danos à natureza, sua transformação em ameaças sociais, econômicas e políticas sistêmicas da sociedade mundial altamente industrializada. Na globalidade da contaminação e nas cadeias mundiais de alimentos e produtos, as ameaças à vida na cultura industrial passam por metamorfoses sociais do perigo: regras da vida cotidiana são viradas de cabeça para baixo. Mercados colapsam. Prevalece a carência em meio à abundância. Caudais de demandas são desencadeados. Sistemas jurídicos não dão contas das situaçôes de fato. As questôes mais prementes provocam desdém. Cuidados médicos falham. Edifícios de racionalidade científica ruem. Governos tombam. Eleitores indecisos fogem. (BECK, 2011, p. 10)

A partir de tais consideraçóes, o certo é que o fenômeno de açóes sem fronteiras surge com os navegadores e descobertas de rotas marítimas para o estabelecimento do comércio entre o Ocidente e o Oriente e vem até os dias atuais com a divisão do mundo em blocos regionais como a União Europeia, o Nafta, o Mercosul e uma tendência gradativa de fragmentação de territórios soberanos.

Assim, a globalização pode ser marcada por três fases distintas: a) período denominado expansionismo mercantilista (1450-1850); b) período era Industrial, imperialista e colonialista (1850-1950); c) período pós-1989 aos dias recentes.

Dito isso, Ulrich Beck (2011) em sua obra Sociedade de Risco apresenta cinco teses para diferenciar a sociedade de risco da sociedade industrial:

$1^{\text {a }}$ tese: $\mathrm{Na}$ sociedade de risco, os riscos e perigos diferem essencialmente daqueles da sociedade industrial e da sociedade pré-industrial: induzem a danos irreversíveis e extrapolam as fronteiras do tempo e do espaço. Os riscos de uma sociedade de risco podem atingir outras sociedades; e os riscos de uma época poderão atingir geraçóes futuras.

Esses riscos geralmente induzem a danos irreversíveis e permanecem invisíveis para a grande parte dos indivíduos, tendo, portanto os cientistas e peritos especializados assumem posição fundamental como intérpretes do perigo velado para a sociedade.

2a tese: Outra tese é a de que há grupos sociais mais afetados na distribuição dos riscos, o que acarreta novos tipos de desigualdade social - as posiçóes sociais do risco. $\mathrm{Na}$ lógica da distribuição dos riscos, um desastre ambiental não 
respeita fronteiras. Ricos e pobres sofrem os efeitos da poluição atmosférica e da contaminação das águas. Todavia, as classes socialmente favorecidas têm melhores condiçóes de remediar os efeitos do risco e de recuperar-se de agravos decorrentes da exposição a uma situação de risco.

3a tese: Beck (2011) considera que a difusão e a comercialização dos riscos náo contradizem a lógica do desenvolvimento capitalista, mas apresentam novos estágios capitalistas, com novos ganhadores e perdedores. As incertezas provocam uma demanda insaciável por segurança e cresce o mercado de produtos do risco.

4a tese: A ciência e a tecnologia apresentam-se como as únicas formas possíveis de apresentar perspectivas aos riscos que criam. A consciência exerce um papel no conhecimento e divulgação do risco. As instituiçóes modernas, responsáveis pelo controle dos riscos que surgem na sociedade de risco, tornam-se inoperantes.

5a tese: A característica da sociedade de risco é constituir- se como uma sociedade catastrófica, na qual o estado "de emergência" passa a ser aceito pela sociedade e pelos indivíduos enquanto um estado "normal", a exemplo da violência urbana. A sociedade catastrófica, como possibilidade política, requer que o poder e a autoridade sejam reorganizados para dar conta das novas demandas sociais.

Tais teses devem ser lidas com as observaçóes de Anthony Giddens (1991, p. 175):

A modernidade é inerentemente globalizante, e as consequências desestabilizadoras deste fenômeno se combinam com a circularidade de seu caráter reflexivo para formar u universo de eventos onde o risco e o acaso assumem um novo caráter. As tendências da modernidade simultaneamente extensionais e intencionais - elas vinculam os indivíduos a sistemas de grande escala como parte da dialética complexa de mudança nos pólos local e global.

Assim sendo, a questão ambiental contemporânea emerge a partir da compreensão dos limites materiais do nosso planeta, onde o uso do espaço é produto das forças sociais criadas ao longo da história, a preservação um fim e os mecanismos legais de proteção um norte.

Desta forma, a insustentabilidade dos modelos de produção vigentes, deflagrada pela incapacidade de recomposição e reequilíbrio dos recursos naturais, somada à constatação da escassez dos recursos naturais, tem exigido da sociedade, uma reflexão sobre nosso futuro comum e, impulsionam uma alteração dos padróes de comportamento da humanidade. 
O dilema do século XXI se revela pela constatação de que o bem ambiental só está a ganhar relevância protetiva na medida em que se torna escasso e o perigo do dano irreversível passa a ser algo concreto.

Com efeito, assim como ocorreu na totalidade das grandes cidades industrializadas do mundo, inúmeras áreas urbanas no Brasil sofrem com os efeitos da industrialização e mais recentemente com o encerramento das atividades industriais sem que medidas ambientais protetivas sejam adotadas.

Esse quadro, no âmbito brasileiro é explicado por Luís Enrique Sanchez (2001, p. 26) da seguinte forma:

a concorrência internacional e o declínio de certos setores industriais vêm somar-se outros fatores que explicam o fechamento de inúmeras indústrias. Um desses fatores é o ambiental, na medida em que velhas indústrias poluentes são objeto de protestos da população do entorno e de regulamentos cada vez mais exigentes quanto à emissão de poluentes.

Com isso tem-se que um imenso passivo ambiental responsável por riscos à segurança, à saúde pública e aos ecossistemas responsável pela poluição do solo.

Desse contexto surge a atualidade do estudo das áreas contaminadas que, no entanto, ainda convivem com sérias falhas na forma de seu gerenciamento em todos os seus estágios, desde a sua formação, prevenção de danos, responsabilização, descontaminação, até a sua efetiva reutilização.

Portanto, a análise das áreas contaminadas e sues inúmeros pontos de vulnerabilidade deveráo nortear o aprimoramento de políticas públicas e dos instrumentos legais e, para tanto é importante uma compreensão dos conceitos fundamentais da temática, como se verá a seguir.

\section{As Áreas Contaminadas}

A lei de Política Nacional do Meio Ambiente destaca em seu art. $2^{\circ}$, caput, que "tem por objetivo a preservação, melhoria e recuperação da qualidade ambiental propícia à vida, visando assegurar, no País, condiçóes ao desenvolvimento socioeconômico, aos interesses da segurança nacional e à proteçáo da dignidade da vida humana" e, para tanto, considera que a saúde e o bem-estar da população, a fauna, a flora, a qualidade do solo, das águas e do ar, a proteção da natureza e da paisagem, a ordenação territorial e o planejamento regional e urbano e a segurança e a ordem pública são bens que devem ser protegidos.

É dentro deste contexto que vamos encontrar o tema das áreas contaminadas.

Por primeiro é importante destacar que no âmbito nacional a temática é tratada pela Resoluçáo 420 do CONAMA, de 28 de dezembro de 2009. A referida resolução dispóe 
sobre critérios e valores orientadores de qualidade do solo quanto à presença de substâncias químicas e estabelece diretrizes para o gerenciamento ambiental de áreas contaminadas por essas substâncias em decorrência de atividades antrópicas.

$\mathrm{Na}$ esfera estadual, atualmente, somente três Estados da federação possuem normatizaçôes sobre as áreas contaminadas: São Paulo, Minas Gerais e Rio de Janeiro.

No Estado de Minas Gerais os documentos que tratam do tema são os seguintes:

a) Deliberação Normativa Copam no 116/2008 - Dispóe sobre a declaração de informações relativas à identificação de áreas suspeitas de contaminação e contaminadas por substâncias químicas no Estado de Minas Gerais;

b) Deliberação Normativa Copam no 2/2010 - Institui o Programa Estadual de Gestão de Áreas Contaminadas, que estabelece as diretrizes e procedimentos para a proteção da qualidade do solo e gerenciamento ambiental de áreas contaminadas por substâncias químicas.

No Estado do Rio de Janeiro a questão é disciplinada pela Resolução do CONEMA no 44/2012, que dispóe sobre a obrigatoriedade da identificação de eventual contaminação ambiental do solo e das águas subterrâneas por agentes químicos, no processo de licenciamento ambiental estadual.

Em São Paulo tem-se o maior arcabouço jurídico a disciplinar a matéria, a saber:

a) Decisão CG no 167/2005 (Corregedoria Geral da Justiça) - Estabelece que a CETESB providencie que a contaminação das respectivas áreas seja averbada à margem do competente registro imobiliário;

b) Decisão de Diretoria no 105-205-E (CETESB) - Dispóe sobre a aprovação dos Valores Orientadores para Solos e Águas Subterrâneas no Estado de São Paulo - 2005, em substituição aos Valores Orientadores de 2001, e dá outras providências;

c) Decisão de Diretoria no 103/2007/C/E (CETESB) - Dispóe sobre o procedimento para gerenciamento de áreas contaminadas;

d) Lei no $13.577 / 2009$ - Dispóe sobre diretrizes e procedimentos para a proteção da qualidade do solo e gerenciamento de áreas contaminadas, e dá outras providências correlatas;

e) Decreto no 59.263/2013 - Regulamenta a Lei $n^{\circ} 13.577$, de 8 de julho de 2009, que dispóe sobre diretrizes e procedimentos para a proteção da qualidade do solo e gerenciamento de áreas contaminadas, e dá providências correlatas.

Considerando que o Estado de Sáo Paulo possui uma lei e um decreto regulamentando a temática daremos ênfase à análise dessa legislação. 
Desta forma, por primeiro o art. 3, II da lei no 13.577/2009 define áreas contaminadas da seguinte forma: "área, terreno, local, instalação, edificação ou benfeitoria que contenha quantidades ou concentraçôes de matéria em condições que causem ou possam causar danos à saúde humana, ao meio ambiente ou a outro bem a proteger".

Sob uma ótica mais ampla, a área contaminada também pode ser caracterizada como uma área cujas concentraçóes de compostos químicos, que causem ou possam causar danos à saúde humana, ao meio ambiente ou a outro bem a proteger estejam acima dos valores de referência permitidos.

A contaminação pode atingir diversos espaços, desde o solo até as águas subterrâneas ou, ainda, se concentrar nas paredes, pisos ou nas estruturas de construçóes.

Sabe-se que os contaminantes são transportados e se propagam de várias maneiras, pelo ar e pelo solo, atingindo as águas superficiais e subterrâneas, por meio da lixiviação, alterando suas características de qualidade, causando impactos e/ou riscos de absorção e adsorção dos mesmos pelas raízes de plantas, verduras e legumes, bem como o escoamento superficial para a água superficial, a inalação de vapores ou o contato, o contato da epiderme com o solo ou a ingestão de tais produtos podem causar sérios problemas para a saúde dos seres humanos e animais.

No entanto, para identificação e caracterização desses danos, é necessária a realização de uma avaliação cujo objetivo é apresentar os aspectos ambientais significativos da área, incluindo as propriedades vizinhas e o referido potencial de impactos ambientais sobre a propriedade em questáo, considerando, principalmente, aspectos de contaminação de solo e águas subterrâneas.

No Estado de São Paulo, o período desenvolvimentista industrial tem início no fim do século XIX, sendo a maioria das indústrias passaram a se fixar em espaços amplos e planos, com proximidade da água e de meios de transporte. $\mathrm{O}$ objetivo não era outro senão o de se livrar dos efluentes ainda não sujeitos a um controle ambiental efetivo e escoar mais facilmente a produção com pouco valor agregado.

Esse modelo perdura por quase todo o século XX, mas a partir da década de 1980, percebe-se um declínio do número de áreas industriais na Região Metropolitana de São Paulo, gerando o surgimento de imóveis desocupados, cujo uso pretérito causou dano no solo e na água subterrânea. Neste sentido, Luís Enrique Sanchez (2001, p. 32) ressalta que, em 1996, a CETESB apontava "3800 estabelecimentos industriais desativados na Região Metropolitana de São Paulo”.

Assim, os passivos ambientais decorrentes de um modelo de produção historicamente alienado das práticas de preservação ambiental, materializado por posturas negligentes e aliado ao dinamismo urbano, foi o responsável por situaçóes de risco, como a implantação de condomínios residenciais, shopping centers e favelas em áreas contaminadas. 
Ademais, como explica Ana Sofia de Barros (2012, p. 125):

A expansão de multinacionais e do investimento direto estrangeiro, facilitada pela desregulação do comércio mundial nas últimas décadas, nem sempre tem sido acompanhada pela consciencialização do papel social da empresa e da responsabilidade que o mesmo acarreta. Em boa verdade, não constituem, e todo, exceção à regra, os exemplos de investimento estrangeiro em que, para lá do lucro, pouco importam quaisquer consideraçôes a nível ambiental ou de saúde humana.

Portanto, o desafio atual é o de gerenciar as áreas contaminadas, mediante a sua localização e comprovação da existência de contaminação, com a implantação de sistemas de remediação e estabelecimento da responsabilidade e custos aos poluidores.

Conforme já destacado a existência de áreas contaminadas é um legado da industrialização, resultado da ineficácia da política pública ambiental brasileira, da inexistência de instrumentos voltados para o controle efetivo da atividade industrial. O referido controle no âmbito do Estado de São Paulo somente tem início no final da década de 1970 com a promulgação da Lei estadual 997/76 e do Decreto regulamentador 8.468/76, que passou a dispor sobre o controle da poluição do meio ambiente.

O mencionado controle passou a ser exercido pela CETESB, criada em 24 de julho de 1968, pelo Decreto no 50.079, com a denominação inicial de Centro Tecnológico de Saneamento Básico.

Posteriormente, no âmbito nacional o licenciamento ambiental das atividades com potencial de contaminação tem início com a publicação da Política Nacional do Meio Ambiente - PNMA (Lei 6.938/81) seguidos das Resoluçóes CONAMA no 001/86 e no $237 / 97$.

Contudo, o município de São Paulo é pioneiro na gestão das áreas contaminadas e vem promovendo a construção de um arcabouço legal específico para tratar da questão desde 1999.

De fato, verificamos que a partir de 2002, a questão começa a ser incorporada nos instrumentos legais do Município de São Paulo. Depois, o Plano Diretor da cidade (Lei no 13.430/2002) estabelece dentre seus objetivos "o controle e a reduçáo dos níveis de poluição e de degradação, controle da poluição da água, do ar e da contaminação do solo e subsolo".

Em seguida é promulgado o Decreto Municipal no 42.319/2002, com as diretrizes para o gerenciamento de áreas contaminadas, e, no ano seguinte, é promulgada a Lei 13.564/2003 que trata dos procedimentos necessários para a aprovação de intervençôes (construçóes, reformas, desdobros, desmembramentos, dentre outros) em terrenos 
contaminados ou suspeitos de contaminação. Essa Lei também traz a possibilidade do controle do uso das denominadas "áreas com potencial de contaminação".

Em 2002, com a criação de legislação específica e instituição da área técnica na Secretaria Municipal do Verde e do Meio Ambiente, o Município de São Paulo passa a atuar na gestão de áreas contaminadas.

E meados de 2003 teve início a inclusão de informaçôes sobre áreas contaminadas no Sistema Municipal de Informação Integrado Municipal, sistematizado no Boletim de Dados Técnicos - BDT, documento que contém uma série de informaçóes sobre os lotes, utilizado pela gestão municipal nos procedimentos para aprovação dos alvarás solicitados.

A Lei 13.885/2004, que complementou o Plano Diretor de 2002, instituiu os Planos Regionais Estratégicos e tratou do ordenamento do Uso e Ocupação do Solo no Município, reforçando o poder municipal na gestão de áreas com passivos ambientais, determinado que as áreas contaminadas só possam ser utilizadas após avaliação ambiental e análise de risco a saúde humana.

No entanto, uma questão controvertida entre os próprios órgãos municipais, principalmente entre aqueles responsáveis pelo controle do uso e ocupação do solo e aqueles responsáveis pelo controle ambiental, é que, a referida lei em seu artigo 201, determina quais atividades devem passar pela investigação ambiental, excluindo outras que também possuem potencial de contaminação, e, portanto, também representam risco a sociedade.

No âmbito estadual, a Secretarias do Estado do Meio Ambiente aliada à CETESB contaram com apoio técnico e financeiro do governo da Alemanha, por meio de sua Agência de Cooperação Técnica - GTZ (Deutsche Gesellschaft für Technische Zusammenarbeit- $G m b H)$ e o resultado desta cooperaçáo foi a produção do Manual de Gerenciamento de Áreas Contaminadas - 2001. O referido manual estabelece procedimentos de gerenciamento e viabiliza a efetiva atuação e encaminhamento de soluçôes.

Além disso, a CETESB é responsável também pela publicação do Relatório de Estabelecimento de Valores Orientadores para Solo e Água Subterrânea, o qual apresenta valores de referência de qualidade, alerta e intervenção para solo e água subterrânea.

Na sequência, em maio de 2002, a CETESB divulgou um cadastro de dados ambientais das áreas contaminadas no Estado de São Paulo disponível para consulta pública. Na ocasião eram 255 áreas contaminadas no Estado de São Paulo e, logo depois, em 2003 foi lançado o Guia para Avaliação de Potencial de Contaminação em Imóveis.

Além dos instrumentos legais, foi criado em 2002 (Portaria 97/SMMA-G/2002) o Grupo Técnico Permanente de Áreas Contaminadas - GTAC, com competência para promover a gestão de áreas contaminadas no território do Município de São Paulo.

A Decisão CG n. 167/2005 - Capital, da Corregedoria Geral da Justiça - Decisão com caráter normativo publicada no Diário Oficial do Estado de São Paulo em 
12.06.2006 - determinou que a CETESB devesse providenciar que a contaminação das respectivas áreas fosse averbadas à margem do competente registro imobiliário.

Em julho de 2009 é sancionada pelo Governo do Estado de São Paulo a Lei no 13.577/09, que dispóe sobre diretrizes e procedimentos para a proteção da qualidade do solo e gerenciamento de áreas contaminadas. Entre outros a lei dá providencias em relação à definição de responsabilidades e os mecanismos de controle das áreas contaminadas, visando garantir o uso sustentável do solo, protegendo-o de contaminaçóes e prevenindo alterações nas suas características e funçóes.

Desta forma a CETESB passou a ter um instrumento de gestão mais efetivo, com a definição de responsabilidades e clareza dos critérios para se identificar áreas com potencial de contaminação e a partir daí todas as etapas técnicas em busca da existência do nexo de causalidade e do dano ambiental.

Entretanto, a referida norma não tem a pretensão de ser um instrumento apto a prevenir o surgimento de novas áreas contaminadas, sua função é estritamente corretiva, restringindo-se apenas em melhorar o gerenciamento dessas áreas.

Logo depois, em dezembro de 2009, a Resolução CONAMA no 420 passou a disciplinar o mesmo tema no âmbito nacional, indicando as diretrizes e critérios orientadores a serem executados de forma padronizada pelos Estados Federativos.

Por fim, em junho de 2013 foi promulgado o Decreto 59.263, regulamentando a Lei 13.577/09, estabelecendo os paramentos necessários para que o Estado fiscalize e acompanhe estas áreas, para que as empresas de consultoria ambiental desenvolvam projetos tecnicamente adequados, bem como para que os responsáveis por elas se responsabilizem pela execução do processo de identificação, investigação, avaliação de risco e estabelecimento de medidas de intervenção, que quando aplicadas auxiliarão no processo de reabilitação destas áreas.

Do referido decreto 59.263/2013 merecem destaque os seguintes dispositivos:

a) Art. $3^{\circ}$ - que traz 38 definiçóes em seus incisos, dentre elas aquelas relativas a Área Contaminada inciso II, Área Contaminada Crítica inciso III, Área Contaminada sob Investigação (ACI), inciso IV; Área Contaminada em Processo de Remediação (ACRe), inciso V; Área Contaminada em Processo de Reutilização (ACRu), inciso VI, Área Contaminada com Risco Confirmado (ACRi), inciso VII; Área com Potencial de Contaminação (AP), inciso VIII, Área em Processo de Monitoramento para Encerramento (AME), inciso IX, Área Reabilitada para o Uso Declarado (AR), inciso X, Área com suspeita de contaminação (AS), inciso XI;

b) Art. 11 - que determina que "Qualquer pessoa física ou jurídica que, por ação ou omissão, possa contaminar o solo deve adotar as providências necessárias 
para que não ocorram alteraçôes adversas e prejudiciais às funçóes do solo", o que equivale dizer que proprietário, o possuidor, o locatário ou ocupante das áreas ser responsabilizados pela contaminação, pois se trata de obrigaçáo propter rem, ou seja, aquela acompanha a propriedade ou a posse do imóvel;

c) Art. 17 - Do responsável pela área com fontes potenciais de contaminação do solo e das águas subterrâneas, a CETESB poderá exigir a manutenção de programa de monitoramento da área e de seu entorno;

d) Art. 22- Em todas as áreas Identificadas como Áreas com Potencial de Contaminaçáo (AP), os responsáveis legais deveráo ser demandados a realizar Avaliação Preliminar para efeito de identificação de indícios ou suspeitas de contaminação;

e) Art. 23 - O responsável legal, ao detectar indícios ou suspeitas de contaminaçáo do sítio deve imediatamente comunicar tal fato à CETESB e ao órgão competente de saúde e realizar a Investigação Confirmatória, sendo que esta sempre deve ser precedida da Avaliação Preliminar;

f) Art. 27 - A realização de Avaliaçáo Preliminar e Investigaçáo Confirmatória independerá de solicitação ou exigência da CETESB;

g) Art. 30 - Determina a criação do fundo de investimento, denominado Fundo Estadual para Prevenção e Remediação de Áreas Contaminadas - FEPRAC, vinculado à Secretaria do Meio Ambiente e destinado à proteçáo do solo contra alteraçôes prejudiciais às suas funçôes, bem como à identificação e à remediação de áreas contaminadas;

h) Art. 45 - Estabelece que o responsável legal pela área contaminada deverá apresentar uma das garantias previstas nos incisos IX e X do artigo $4^{\circ}$ da Lei ${ }^{\circ}$ 13.577, de 8 de julho de 2009, a fim de assegurar que o Plano de Intervençáo aprovado seja implantado em sua totalidade e nos prazos estabelecidos, no valor mínimo de $125 \%$ (cento e vinte e cinco por cento) do custo estimado no respectivo plano.

i) Art.56 - Dita que os responsáveis legais por empreendimentos sujeitos ao licenciamento ambiental e potenciais geradores de contaminação, a serem total ou parcialmente desativados ou desocupados, deverâo comunicar a suspensão ou o encerramento das atividades no local à CETESB;

j) Art. 62 - Para efeito de edificação em Áreas com Potencial de Contaminação (AP) exige-se avaliação da situação ambiental da área a ser submetida ao órgáo municipal competente, podendo para tanto ser consultada a CETESB; 
k) Art. 97 - O licenciamento de empreendimentos nas áreas que anteriormente abrigaram atividades com potencial de contaminação, ou suspeitas de contaminação devem ser precedidos de estudo de passivo ambiental, submetido previamente ao órgão ambiental competente.

Diante da leitura de tais dispositivos tem-se que as ações técnicas quando adequadamente desenvolvidas, observando as premissas estabelecidas pela CETESB e alinhadas com a legislação de áreas contaminadas, servirão como base para ocupação segura, considerando riscos aceitáveis tanto por trabalhadores como por moradores destas áreas.

O Estado de São Paulo conta, atualmente, com 4.771 áreas contaminadas, segundo o último levantamento da CETESB, publicado em Dezembro de 2013. Desse total, 3.597 são áreas de postos de gasolina, 232 têm origem em atividades comerciais e 768 decorrentes de processos industriais. Além disso, 136 áreas foram causadas por disposição de resíduos e 38 decorrentes de acidentes, de autoria desconhecida ou agricultura. Dessas áreas, 264 são consideradas reabilitadas, conforme apresentado nos gráfico abaixo.

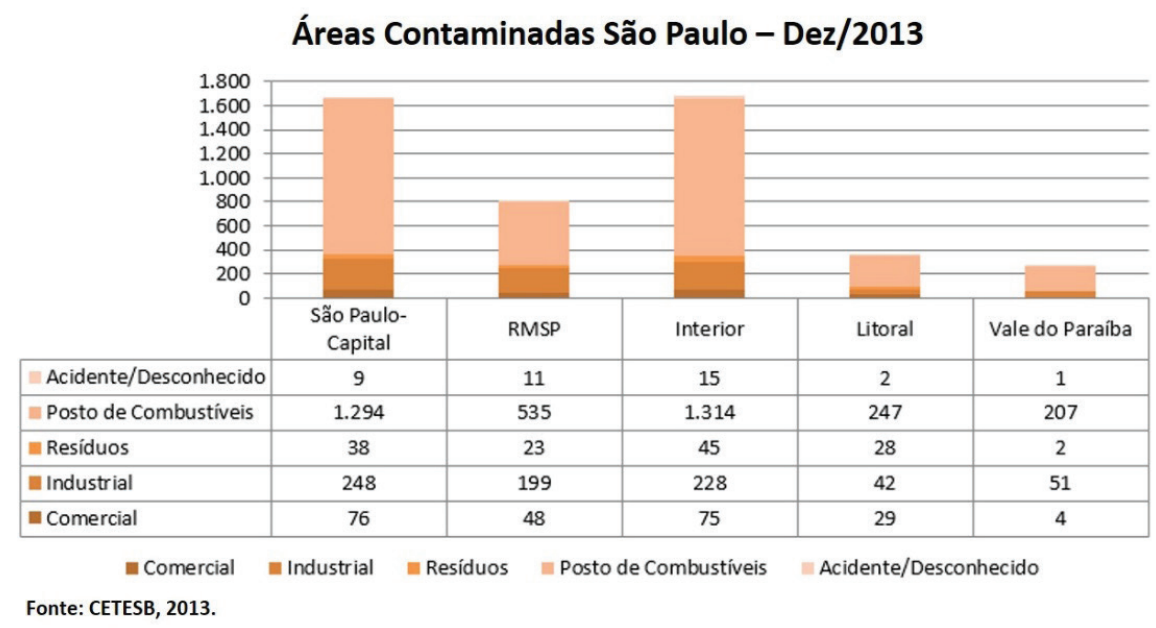

Constata-se que $75 \%$ do número total de áreas contaminadas no Estado de São Paulo é atribuída aos postos de gasolina, o que exige, segundo a Decisão de Diretoria no 263/2009/C/E da CETESB, a realização da investigação confirmatória com o objetivo de verificar a situação ambiental do empreendimento a ser licenciado, bem como a realizaçáo da troca dos tanques de armazenamento de combustível com mais de quinze anos de operação.

Em comparação com os outros Estados da federação tem-se o seguinte: 
a) Em Minas Gerais, 369 existem áreas contaminadas com dados apresentados pela FEAM (Fundação Estadual do Meio Ambiente) em 2014, sendo que dessas áreas, 259 são referentes a postos de combustíveis; 49 relacionadas com Metalurgia; 40 na área de ferrovia; 12 referentes às indústrias químicas; 10 no setor de mineração; 3 relativas a resíduos sólidos; 2 ligadas ao refino de óleo e 3 nas áreas de aeroporto, dutos e reciclagem, conforme explicita o quadro abaixo:

Áreas Contaminadas Minas Gerais - 2014

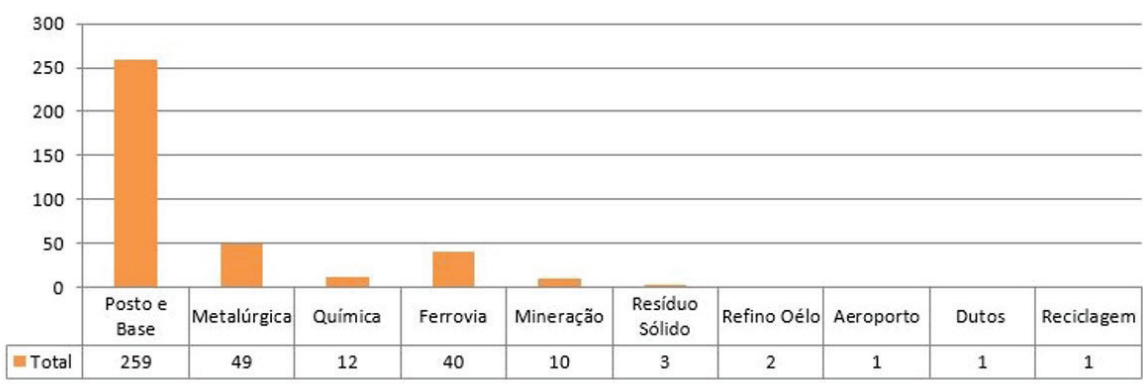

Fonte: FEAM, 2014.

b) No Rio de Janeiro, existem 277 áreas contaminadas cadastradas, com dados apresentados pelo INEA (Instituto Estadual do Ambiente), em 2014, sendo que dessas áreas, 158 são referentes a postos de combustíveis; 98 referente a áreas industriais; 10 relacionadas com aterros e 11 com o ramo da aviáo, consoante se verifica no quadro abaixo.

\section{Áreas Contaminadas Rio de Janeiro- 2014}

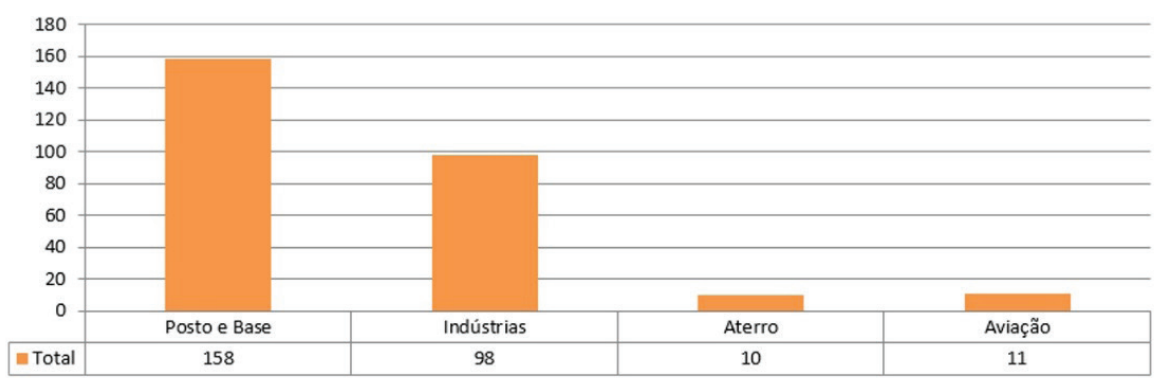

Fonte: INEA, 2014.

Entretanto, esses números correspondem ainda a uma ínfima parcela da realidade. Estima-se, com base no histórico da industrialização, que haja aproximadamente 36.000 áreas com potencial de contaminaçáo somente no Estado de Sáo Paulo, das quais, poucas 
passaram pelas investigaçóes ambientais ora apresentadas e, por ser assim, continuam a colocar em risco a sua saúde da população e os sistemas naturais.

Por fim, são necessárias algumas palavras sobre a recuperação das áreas contaminadas. De plano é conveniente deixar claro que o direito a propriedade no Brasil não é absoluto e deve atender ao seu papel social, nos moldes do art. 5º inciso XXIII da CF/88. Além disso, o art. 1.228, $\$ 1^{\circ}$ do Código Civil (Lei no 10.406/2002) determina que o direito de propriedade deve exercido em consonância com as suas finalidades econômicas e sociais, de modo que sejam preservadas a flora, a fauna, as belezas naturais, o equilíbrio ecológico e o patrimônio histórico e artístico, bem como evitada a poluição do ar e das águas.

Desta forma, o processo de identificação de uma área contaminada envolve etapas de identificação, diagnóstico e intervenção, sendo que cada etapa segue uma norma específica. Assim uma área suspeita deve ser submetida à realização de uma Avaliação Preliminar. Este estudo pesquisará o histórico de ocupação e das atividades ali desenvolvidas, nos moldes da ABNT NBR 15515-1. Com esse estudo elabora-se um Modelo Conceitual indicando aspectos ambientais relevantes da área em estudo, tal como dita a ABNT NBR 16210 - Modelo conceitual no gerenciamento de áreas contaminadas - Procedimento. Ainda dentro do processo de identificação, o resultado do modelo conceitual indica se há ou não a necessidade de realizar uma Investigação Confirmatória - ABNT NBR 15.5152. Com o resultado dessa segunda etapa, onde são realizadas sondagens, coleta de amostras de solo e água subterrânea, análises químicas e interpretação dos dados é possível determinar se existem ou não passivos ambientais na área.

Confirmada a existência de passivo ambiental, ou seja, comprovada a alteraçáo na qualidade do solo e/ou água subterrânea, faz-se necessária a realização da Investigação Detalhada, cujo objetivo é obter uma avaliação hidrogeológica e hidroquímica detalhada, com a determinação de concentraçóes dos compostos químicos em diferentes profundidades, visando conhecer a distribuiçáo vertical dos compostos de interesse, possibilitando a delimitação de plumas de isoconcentraçóes para os compostos de relevância ambiental nas águas subterrâneas, de acordo com a norma ABNT NBR 15.515-3.

A fase da avaliação de risco à saúde humana é o passo seguinte. Essa etapa é utilizada para estimar o risco à saúde humana causada pela exposição a uma determinada substância ou grupo de substâncias presentes no meio físico (solo, sedimento, água subterrânea, água superficial e ar) e para estabelecer metas que orientem as medidas de intervenção. O processo de avaliação de risco segue as diretrizes estabelecidas na ABNT NBR 16209 - Avaliação de risco a saúde humana para fins de gerenciamento de áreas contaminadas.

Por fim, com a avaliação do risco, tem-se a possibilidade de remediar a contaminação e, para tanto se examina as intervençôes necessárias para cada local, visando atingir níveis aceitáveis. 
Existem diversas técnicas de remediação no mercado, sendo possível utilizar uma ou várias delas associadas, destacando as mais usuais: sistema de extração de vapores; sistema Air Sparning; processos oxidativos avançados (POA); sistema de extração multifásica (MPE); atenuação natural monitorada; barreiras reativas, barreiras hidráulicas; sistema bombeamento (pump and tread); biorremediação.

Desta forma, a remediação é pautada pelo conhecimento do meio físico (solo, ar ou água), pelo conhecimento do contaminante (móvel, solúvel, tóxico, explosivo) e pelo conhecimento das demandas (ambientais, saúde pública, legais, sociais, corporativas). Com isso seleciona-se o processo de remediaçáo, que pode envolver o emprego de tecnologia consagrada ou piloto, um conjunto de tratamentos, a operaçáo e manutençáo do sistema e o custo para a aquisição do sistema escolhido, sendo que tudo deve ser pautado pela confiabilidade operacional, custos e o tempo para remediar uma área, com o emprego da tecnologia, que poderá envolver o tratamento do contaminante no próprio solo, sem a sua movimentação (in situ), ou a remoção do solo contaminado (ex situ), ou, ainda, com a remoção do material contaminado, mas com o tratamento em estaçóes instaladas no local (ex situ, on site).

\section{Conclusões}

Ao longo do presente texto pudemos constatar que a ineficácia da implementação dos instrumentos de precaução e prevenção, tem gerado o aumento dos riscos e dos perigos industriais, requerendo assim a utilizaçáo corriqueira do sistema de reparação.

Para maior eficácia das ações do poder público nesta área é preciso inserir o tema na agenda política dos Estados e integrá-lo com as políticas públicas, pois a questão da análise das áreas contaminadas exige uma leitura sistêmica para sua solução, sendo que a avaliação ambiental deve ser considerada desde o início do processo da aprovação de empreendimentos ou intervenções no solo e não ao final, como historicamente ocorre.

Tem-se que o arcabouço legislativo ambiental brasileiro é avançado, eis que consagra diversos instrumentos preventivos. Entretanto, o poder público não tem sido eficaz na sua aplicação e, em grande parte das vezes ainda se apresenta como omisso na implementação dos instrumentos administrativos, o que gera um aumento desenfreado dos danos ambientais.

Vê-se, assim, que no âmbito do Direito Ambiental, a resposta jurídica para um determinado problema, na maioria das vezes, só surge quando este se apresenta, pois pouco ou quase nenhuma é a atuação no âmbito da prevenção e da precaução.

Urge, pois, que um dos princípios basilares do direito ambiental, o Princípio da Prevenção, passe a ser aplicado com maior intensidade para se estabelecer um novo paradigma, 
no qual uma política pública de prevenção pudesse nortear a implantação dos novos empreendimentos de modo respeitar padróes de qualidade do solo para evitar novos sítios de contaminação.

De fato, apesar das restriçóes de ordem legal, a histórica permissividade dos administradores brasileiros, aliada à tolerância aos diversos usos e exploraçóes do solo traduz-se hoje em impactos ambientais de variadas ordens, provenientes da sociedade de risco que, por vezes ainda, representam risco à saúde humana.

Desta maneira tem-se que as áreas contaminadas representam risco à saúde pública e ao ambiente. São provenientes da sociedade contemporânea, também chamada de sociedade de risco e surgiram em decorrência da forma como o conhecimento técnicocientífico foi aplicado no processo produtivo.

Essa questão tem desafiado o poder público e a própria sociedade na busca por soluçóes e medidas mitigadoras que garantam a utilização segura de áreas impactadas.

No entanto, é de extrema importância entender que a recuperação e revitalização de áreas contaminadas não devem ser consideradas somente do ponto de vista urbanístico e de controle de fontes de poluição, mas principalmente como uma questáo de saúde pública, eis que se encontram intrinsecamente envolvidos uma série de fatores, dentre os quais os aspectos legais, econômicos e sociais.

Os altos custos envolvidos nas investigaçốes e nas medidas de remediação para reutilização de uma área impactada, bem como o tempo para reabilitação, explica, em parte, a resistência da iniciativa privada em atender a legislação. A isso se une a omissão do Poder Público na fiscalização e cumprimento da responsabilização dos poluidores.

Porém, se faz urgente que ocorram mudanças no campo do conhecimento, do comportamento das instituiçóes, da atuação do poder público e no comportamento individual de cada cidadão em relação à temática apresentada.

Essa transformação deve partir da ética ambiental e estar associada à educação, cultura e a reformulação do conceito de progresso, com a introdução e difusão dos preceitos de desenvolvimento sustentável, que reconheça que a Terra ainda é o nosso único lar. Com ele busca-se quebrar a dicotomia entre desenvolvimento e conservaçáo, a qual permitiu que os setores mais retrógrados da sociedade se apresentassem como os promotores do crescimento, gerador de emprego e renda, em contrapartida aos conservacionistas, por eles caracterizados como obstáculo a esse anseio social.

Entretanto, o conceito de desenvolvimento sustentável não pode ser visto como um álibi ou um mito que atende os interesses econômicos, sob o argumento falacioso do crescimento, que desfigura o planeta e o contamina com dejetos de atividades criminosas, mantidas por políticas tendenciosas. 
Deve existir clareza da humanidade de que há um limite para o crescimento e que envolve a relação entre resistência ambiental e potencial biótico. Esta é a possibilidade que a população encontra de sobrevivência em um ambiente propício, enquanto aquela é o fator que impede que as populaçóes cresçam conforme o seu potencial biótico, ou seja, fatores limitadores do crescimento, tais como espaço, clima, alimento, competiçáo, parasitismo e predação.

Assim, não são as necessidades legitimas que norteiam o desenvolvimento atual e que pressionam pela destruição dos ecossistemas remanescentes, mas sim os segmentos de políticas públicas idealizadas para atender determinados setores da economia.

Nesse sentido, é preciso desenvolver um programa para gerenciamento das áreas contaminadas no Brasil e não apenas em alguns estados da federação, com critérios metodológicos para identificação, gestão e remediação dessas áreas.

De fato, embora a Resolução 420 do CONAMA tenha determinado em seu art. 8 (com redação dada pela Resolução 460 do CONAMA) que os Estados e o Distrito Federal deveriam estabelecer os Valores Orientadores de Referência de Qualidade (VRQs) até dezembro de 2014, decorrido o prazo verifica-se que somente o Estado de São Paulo possui uma legislação específica sobre o tema e, os Estados de Minas Gerais e Rio de Janeiro cumpriram as determinaçóes e publicaram cadastros das áreas contaminadas.

Tudo nos leva a concluir que o tema ainda não entrou na agenda política brasileira, sendo que a complexidade envolvida e que permeia o dano ambiental ultrapassa um olhar jurídico e meramente dogmático, exigindo-se um olhar multidisciplinar imprescindível para correta aplicação dos princípios da prevenção e da precaução, superando o modelo reativo de inação frente aos passivos ambientais, para um modelo proativo, no qual acha uma antecipação para se evitar uma situação de risco, surgindo um novo modelo para além do vigente na sociedade de risco.

\section{Referências}

BARROS, Ana Sofia. Multinacionais e a Deslocalização de Indústrias Perigosas: ensaio sobre a proteçáo dos direitos humanos perante o dano ambiental. Lisboa: Coimbra Editorial. 2012.

BECK, Ulrich. Sociedade de risco: rumo a uma outra modernidade. 2a edição. São Paulo: Editora 34, 2011.

\section{. O que é Globalização? Equívocos do globalismo - Respostas à Globalização.}

São Paulo: Terra e Paz. 1999.

BOFF, Leonardo. Saber cuidar: ética do humano - compaixão pela terra. Petrópolis:

Vozes, 2011. 
BRASIL. RD no 023/00/C/E, de 15.06.2000 - Implantação de procedimentos para o gerenciamento de áreas contaminadas Decisão CG N. 167/2005 - 12/06/2006 - Capital, da Corregedoria Geral da Justiça. Disponível em: http://www.mpsp. mp.br/portal/page/portal/cao_urbanismo_e_meio_ambiente/legislacao/leg_estadual/leg_est_decisoes/\%C3\%A1reas\%20contaminadas\%20-\%20averba\%C3\%A7\%C3\%A3o\%20no\%20RI.doc . Acesso em 25.abr.2015.

. Código Civil (lei no 10.406 de 10 de janeiro de 2002). Disponível em: http:// www.planalto.gov.br/ccivil_03/leis/2002/110406.htm Acesso em 28.abr.2015.

. Constituiçáo da República Federativa do Brasil, de 05 de outubro de 1988. Diário Oficial da Uniáo, Brasília, DF. Disponível em: http://www.planalto.gov.br/ ccivil_03/constituicao/constituicao.htm. Acesso em 28.abr.2015.

. Lei no 6.938 de 31 de agosto de 1981. Dispóe sobre a Política Nacional do Meio Ambiente, seus fins e mecanismos de formulação e aplicação e dá outras providências. Disponível em: http://www.planalto.gov.br/ccivil_03/leis/16938.htm. Acesso em: 25.abr.2015.

. Lei 12.527 de 18 de novembro de 2011. Disponível em: http://www.planalto. gov.br/ccivil_03/_ato2011-2014/2011/lei/112527.htm. Acesso em 28.abr.2015.

. Resoluçáo CONAMA n ${ }^{\circ} 001$ de 23 de janeiro de 1986. Dispóe sobre as definiçóes, responsabilidades, critérios básicos e diretrizes gerais para uso e implementação da Avaliação de Impacto Ambiental como um dos instrumentos da Política Nacional do Meio Ambiente. Disponível em: http://www.mma.gov.br/port/conama/res/ res86/res0186.html. Acesso em:15.abr.2015.

. Resoluçáo CONAMA n 237 de 19 de dezembro de 1997. Dispóe sobre a definição de licenciamento ambiental, licença ambiental, estudos ambientais e impacto ambiental regional e revoga dispositivos da Resolução CONAMA 001 de/1986. Disponível em: http://www.mma.gov.br/port/conama/res/res97/res23797.html Acesso 25.abr.2015.

. Resoluçáo CONAMA n ${ }^{\circ} \mathbf{4 2 0}$ de 28 de outubro de 2009. Dispóe sobre critérios e valores orientadores de qualidade do solo quanto à presença de substâncias químicas e estabelece diretrizes para o gerenciamento ambiental de áreas contaminadas por essas substâncias em decorrência de atividades antrópicas. Disponível em: http:// www.mma.gov.br/port/conama/legiabre.cfm?codlegi=620. Acesso em 25.abr.2015.

. Supremo Tribunal Federal. Medida Cautelar em Açáo Direta de Inconstitucionalidade 3.540-1 - Distrito Federal (ADI 3.540 - MC/DF). Relator: Ministro Celso de Melo. Julgado em 01 de setembro de 2005. Diário de Justiça, Brasília, 03 fev. 2006. Disponível em: http://www.stf.jus.br/imprensa/pdf/adi3540ementa.pdf. Acesso em: 28.01.2015. 
CETESB. Manual de Gerenciamento de Áreas Contaminadas. São Paulo: CETESB/ GTZ, 2001. Disponível em: http://www.CETESB.sp.gov.br/areas-contaminadas/ manual-de-gerenciamento-de-ACs/7-. Acesso em 28.04.2015.

. Cadastro de áreas contaminadas. 2006. Disponível em: http://www.CETESB. sp.gov.br/areas-contaminadas/rela\%E7\%F5es-de-\%E1\%A1reas-contaminadas/ 4-rac. Acesso em 28.abr.2015.

. Decisáo de Diretoria No 103/2007/C/E de 22 de junho de 2007. Dispóe sobre o procedimento para gerenciamento de áreas contaminadas. Acesso em 15.mai.2015. Disponível em: http://www.cetesb.sp.gov.br/Solo/areas_contaminadas/proced_gerenciamento_ac.pdf. Acesso em 25.abr.2015.

ESTADO DE SÃO PAULO. Lei no 13.577 de 8 de julho de 2009. Dispóe sobre diretrizes e procedimentos para a proteção da qualidade do solo e gerenciamento de áreas contaminadas, e dá outras providências correlatas. Disponível em: http://www. al.sp.gov.br/repositorio/legislacao/lei/2009/lei-13577-08.07.2009.html. Acesso em 25.abr.2015.

Decreto No $\mathbf{5 4 . 5 4 4}$ de 08 de julho de 2009. Regulamenta o inciso XIII do artigo $4^{\circ}$ e o inciso VIII do artigo 31 da Lei no 13.577. Disponível em: http://www. al.sp.gov.br/repositorio/legislacao/decreto/2009/decreto-54544-08.07.2009.html Acesso em 28.abr.2015.

. Decreto No 59.263, de 5 de Junho de 2013. Regulamenta a Lei no 13.577, de 8 de julho de 2009, que dispóe sobre diretrizes e procedimentos para a proteçáo da qualidade do solo e gerenciamento de áreas contaminadas, e dá providências correlatas. Disponível em: http://www.al.sp.gov.br/repositorio/legislacao/decreto/2013/ decreto-59263-05.06.2013.html. Acesso em 25.abr,2015.

. Lei No 997 de 31 de maio de 1976. Dispóe sobre o controle de poluição ambiental. Disponível em: http:/www.al.sp.gov.br/repositorio/legislacao/lei/1976/lei997-31.05.1976.html. Acesso em 25.abr.2015.

. Decreto No 8.468 de 08 de setembro de 1976. Aprova o Regulamento da Lei n. 997, de 31 de maio de 1976, que dispóe sobre a Prevenção e o Controle da Poluição do Meio Ambiente. Disponível em: http://www.al.sp.gov.br/repositorio/legislacao/ decreto/1976/decreto-8468-08.09.1976.html. Acesso em 25.abr.2015.

GUIDDENS, Anthony. As consequências da modernidade. Tradução Raul Fiker. São Paulo: Editora Unesp, 1991.

LEITE, José Rubens Morato; AYALA, Patryck de Araújo. Direito ambiental na sociedade de risco. Rio de Janeiro, Forense Universitária, 2002. 
MACHADO, Paulo Affonso Leme Machado. Direito ambiental Brasileiro. 19. Ed. São Paulo: Malheiros editores, 2012.

. Direito à Informação ambiental. São Paulo: Malheiros, 2006.

MUNICÍPIO DE SÃO PAULO. LEI No 13.430 de 13 de setembro de 2002. Dispóe sobre o plano diretor estratégico. Disponível em: http://www.prefeitura.sp.gov.br/ cidade/upload/b9e06_Lei_N_13.430-02_PDE.pdf. Acesso em: 25.abr.2015.

LEI No 13.564, de 24 de abril de 2003. Dispóe sobre a aprovação de parcelamento de solo, edificação ou instalação de equipamentos em terrenos contaminados ou suspeitos de contaminação por materiais nocivos ao meio ambiente e à saúde pública. Disponível e: http://www.prefeitura.sp.gov.br/cidade/secretarias/habitacao/ plantas_on_line/legislacao/index.php?p=7848 Acesso em 25.abr.2015.

. DECRETO No 42.319 de 30 de janeiro de 2002. Dispóe sobre diretrizes e procedimentos relativos ao gerenciamento de áreas contaminadas no Município de São Paulo. Disponível em: http:/www.prefeitura.sp.gov.br/cidade/secretarias/habitacao/ plantas_on_line/legislacao/index.php?p=12685 Acesso em 28.abr.2015.

LEI No 13.885, de 25 de agosto de 2004. Dispóe sobre o parcelamento, disciplina e ordena o uso e ocupação do solo do município de São Paulo e estabelece normas complementares ao plano diretor estratégico, institui os planos regionais estratégicos das subprefeituras. Disponível em: http://www.prefeitura.sp.gov.br/ cidade/upload/1da2a_Lei_N_13.885-04_Estabelece_normas_ao_PDE.pdf Acesso em 28.abr.2015.

NALINI, José Renato. Ética ambiental. Campinas: Milennium, 2010.

ORGANIZAÇÓES DAS NAÇÓES UNIDAS. Declaração do Rio sobre Meio Ambiente e Desenvolvimento.Disponível em: http://www.onu.org.br/rio20/img/2012/01/ rio92.pdf. Acesso em 21.mar.2015.

SÁNCHEZ, Luiz Enrique. Desengenharia: O Passivo Ambiental da Desativação de Empreendimentos Industriais. São Paulo: EDUSP, 2001.

SOUZA, José Fernando Vidal de. Água: Fator de desenvolvimento e limitador de empreendimento. São Paulo: Modelo, 2011.

SOUZA, J. F. V.; DUTRA, Tonia Andrea Horbatiuk. Alteridade e Ecocidadania: uma ética a partir do limite na interface entre Bauman e Lévinas. Cadernos de Direito (UNIMEP), v. 11, p. 07-22, 2011. 